\title{
Sacrificing the Career or the Family?
}

\section{Orthodox Jewish Women between Secular Work and the Sacred Home}

\author{
Chia Longman
}

\author{
GHENT UNIVERSITY
}

ABSTRACT This article addresses the question of women's agency in traditionalist religion, through a study of self-narratives by women in the Orthodox Jewish community of Antwerp, Belgium. Women who study or work outside the boundaries of their community were interviewed about their experiences in negotiating gender ideologies by moving in and between the 'secular' and 'religious' spaces of higher education, work and home. Various subject positions emerged in terms of either rejecting, separating or reconciling dominant community norms regarding women's proper role with personal trajectories of self-realization and individual autonomy. On the one hand, the results confirm the possibility of women's agency within religious-traditionalist settings and in that sense subscribe to some recent feminist theoretical challenges to secularism. However, it is argued that the younger generation faces more restrictions in negotiating religious and secular gender-role expectations in the Antwerp context. Their prospects depend on the dynamic between global fundamentalist tendencies and local liberal state policies of multicultural accommodation.

KEY WORDS Antwerp $\bullet$ feminist theory $\bullet$ fundamentalism $\bullet$ life-stories $\bullet$ multiculturalism $\bullet$ Orthodox Judaism $\bullet$ secularism $\bullet$ women's religious agency

\section{INTRODUCTION: THE RELIGION QUESTION IN FEMINISM}

Recent years have seen a proliferation in research on the position and participation of women in religious-traditionalist communities. One of the implications has been a discussion of the challenges this work may pose to

European Journal of Women's Studies Copyright (C) 2008 SAGE Publications

(Los Angeles, London, New Delhi and Singapore), 1350-5068 Vol. 15(3): 223-239;

http:/ / ejw.sagepub.com DOI: 10.1177/1350506808091505 
the hegemony of secularism within feminist theory. ${ }^{1}$ Erstwhile paradigms of religious women as 'cultural dopes' or 'victims of false consciousness' have been superseded by the insight that they actively negotiate rather than passively submit to or reproduce patriarchal structures and ideologies. Generally, the Foucauldian insight that 'power accompanies resistance' and the reworking of ideas of submission and subversion through the notion of 'agency' are increasingly being employed in the feminist study of religion potentially recasting secular and liberal conceptions of autonomy, empowerment and liberation (see Brink and Mencher, 1997; Mack, 2003; Mahmood, 2005; Pritchard, 2006). Whereas much of this research has dealt with topics such as activism, embodiment and piety in movements within religious traditions such as Hinduism, Christianity and Islam, in this article a case study in Orthodox Judaism is presented with the aim of making an additional contribution to the ongoing debate on the vexed relationship between feminism and religion.

Contemporary Orthodox Jewish communities follow rabbinical tradition, which is very much practice- and ritual-oriented; submission to God is expressed through an elaborate system of life-guiding laws - the halakhah. As for its gender ideology, similar to many other traditionalist societies and kinds of identity politics, women's role in Orthodox Judaism is circumscribed according to a patriarchal heteronormative framework. The control over women's sexuality and behaviour is expressed through norms of modesty, chastity and privacy, with an emphasis on their domestic role as mother, carer and homemaker (Longman, 2007). Hence, as opposed to the modern ideal of individual autonomy, a woman's lot is defined in terms of her relational capacities and reproductive value vis-avis her husband, children, family and the wider community.

Some studies have nevertheless drawn attention to the way traditionalist women are often critical of the western liberal feminist subject, when the masculine ideal is emulated to the detriment of an ideology of sexual difference and the devaluation of female rituals and spirituality, motherhood, child-rearing, women-only space, an 'ethic of care' and the private and domestic sphere (Kaufman, 1993; Klatch, 1994). Research that attends to the voices or standpoints of religious-traditionalist women themselves can therefore provide a critical engagement with feminist secular thought on concepts of self, agency and empowerment. Can religious gender norms simply be interpreted as oppressive of women, or can principles such as modesty, gender separatism and role differentiation and relational autonomy (Mackenzie and Stoljar, 2000) be understood as empowering for women? Furthermore, what are the implications of possible answers to such questions for the relationship between gender equality and cultural and religious diversity in the context of a liberal democratic multicultural state (see Phillips, 2007; Shachar, 2001)?

In this article, some of these questions are explored through a case study among 'exceptional' women in the Orthodox Jewish community of 
Antwerp. It is contended that women who in various idiosyncratic ways cross the boundaries between their own community and the surrounding society, prove most challenging for a gender analysis of religious vitality and secularism in the context of liberal society. ${ }^{2}$ Using the method of lifestories, this study aims to uncover the strategies and experiences of women who have implicitly or explicitly challenged and negotiated community gender norms founded and legitimated in traditional Judaism, by their participation in activities such as education and paid work in the surrounding secular society. Religious gender ideologies of sexual difference potentially conflict with institutionalized gender equality in western liberal democracies. How do religious women combine and negotiate gender-role expectations such as marriage and motherhood with personal ambition and public or professional activities? Conversely, are certain religious gender norms capitalized on that can enhance female agency and identity? To what extent can belonging to a religious-traditionalist ethnic community coexist with modernist forms of female agency and autonomy, or does this study show that notions and dichotomies of the private vs the public, the religious vs the secular, tradition vs modernity, and feminism vs multiculturalism can ultimately be called into question?

\section{WOMEN'S SELF-NARRATIVES IN THE ANTWERP SHTETL}

Methodologically, life-stories were gathered through individual indepth qualitative interview sessions, usually at the informants' homes. Self-narratives allow an insight into how individuals 'make sense' of their past and present experiences, their personal selves and their social identity. With regard to this commonly employed method in feminist research (e.g. Gluck and Patai, 1991), Bloom (1998: 144) argues that women's life-stories challenge the traditional notion of unified subjectivity in that they express the individual tensions and contradictions that necessarily exist as a result of the different ways each woman identifies herself in socially situated ways'. Besides gender, from an intersectional perspective, the cultural models or constitutive 'narrative scripts' and subject positions available are also always determined by dominant understandings of racial, ethnic, class, sexual and, I might add, religious identities (Prins, 2006). Buitelaar (2006: 273) claims that narratives can be analysed as 'dialogues between various voices within the self, each one embedded in field-specific repertoires of practices, characters and discourses informed by specific power relations'. Lifestory analysis therefore gives insight into the situated and complex negotiation between mutually constitutive discursive personal selves and dominant sociocultural norms and relations to which the narrator is subjected. This subjection can also be viewed as agentic in that norms 
may, for example, be reproduced, reinterpreted or subverted, especially at times when multiple identifications and normative commitments are experienced as conflicting.

In this study, Orthodox Jewish women were invited to narrate their choices, feelings, desires, compromises, regrets, successes, relations and experiences of harmony, ambiguity, conflict, etc., pertaining to life experiences such as childhood, adolescence, education, marriage, motherhood and profession. The interview analysis focused on the various subject positions within and among individual women negotiating between their own self-identity and both religious traditionalist and secular liberal gender norms. Attention was paid to the way in which these narrative dichotomies were potentially deconstructed such as those between the private and the public, the self and other, and religious traditionalism vs secular modernity.

From 2005-7 some 20 interviews were carried out with women who self-identify as Orthodox Jewish and who currently live in Antwerp. The Jewish community in Antwerp is relatively small (approx. 20,000), yet unique in that a great part of the community can be identified (at least nominally) as religiously observant to varying degrees in abidance to halakhah (Jewish law), circumscribing a range of ethical, legal and ritual precepts and practices regulating daily life, from participation in more public services (synagogue study, prayer and lifecycle celebrations) to abiding by the dietary laws (kashrut), honouring the weekly Shabbat and celebrating numerous holy days throughout the year.

Antwerp is also home to various Haredim or strictly Orthodox Jews (including branches among the Hassidim and Mitnagdim ${ }^{3}$ ), members of distinct types of extremely observant and contra-acculturative groups. Haredi Jews are often designated as the most traditionalist or even fundamentalist on the Orthodox continuum, whereas the label 'Modern Orthodox' is commonly applied to those observant Jews who strive to combine religious practice and identity with a modern lifestyle and participation in the secular world. Although the Haredi community is a minority (est. 5000-8000), it nevertheless has a distinct impact on the character of all of Antwerp Jewry, including its networks and institutions, which gives the Jewish area its unique 'Hassidic flavour' and the title of a 'contemporary shtetl', reminiscent of the old-style East European Jewish towns.

\section{GENDER ROLES IN ORTHODOX JUDAISM}

Orthodox Jewish law is characterized by the requirement to fulfil certain obligations according to one's role, which to a certain extent is intrinsically gendered, in contrast to a rights-based system as in modern liberal philosophy. According to the halakhah, women are exempt from a number of 
positive commandments (mitzvoth) that are incumbent upon men. For instance, women may not practise certain rituals, such as wearing the tefillin (phylacteries or prayer straps) and the tallit (prayer shawl) during the Morning Prayer. The most commonly applied justification for such exemptions is that the performance of such obligations bound to set times would only interfere with the woman's daily family and household responsibilities.

However, women are also exempt (and according to some interpretations barred) from the study of Talmud (Oral Law), which is considered a most important religious obligation upon men. The result is that women have historically come to be excluded from halakhic discussions, decisionmaking processes and leadership positions such as rabbi or judge. Due to requirements of modesty, women similarly do not participate actively in certain public rituals such as leading prayers, reading from a Torah scroll and singing in men's presence. Just as in many other patriarchal legal systems, in traditional Jewish family law women usually have a dependent, inferior position with regard to regulations in marriage, divorce, financial status and inheritance. Despite these inequalities, in practice the contemporary position and role of women nevertheless varies considerably depending on the degree of Orthodoxy, class and community in question.

Due to the relative smallness and cohesiveness of Antwerp Jewry, a priori categorizations in terms of 'strict' vs 'modern' Orthodox did not function as selection criteria for this case study. Although the lifestyle, gender-role expectations and restrictions of their circles varied, halakhicobservant adult women of different ages and backgrounds were sought who have transgressed the 'normative' in that they follow or have followed higher secular education, or are active in professions within and beyond the boundaries of their own community. It was soon understood that compared to developments within other communities in Israel, North America and the UK, Orthodox women studying or working in secular society in Antwerp are relatively rare.

\section{ORTHODOX GIRLS' EDUCATION: PREPARING FOR MARRIAGE AND MOTHERHOOD?}

A number of my Orthodox interviewees ${ }^{4}$ claimed that they had enjoyed a somewhat unusual upbringing in that they had been brought up according to a more 'open-minded' philosophy that emphasized the necessity to achieve at least some form of higher secular education, degree or skill. Thus 50-year-old Chaya, the director of a Jewish community institution for disabled children, explained that her father wanted his daughters to have 'at least something in their hands' before marriage. Like the majority of my interviewees, Chaya had attended the local Orthodox Beis Yacoov secondary school for girls, ${ }^{5}$ and as the only girl in her class who 
went on to pursue a degree, in orthopaedics, at a regular college, was the last to marry, at the age of 21 - just after graduation. My interviewees of different ages and generations all claimed that the norm was for young Orthodox women to marry between the ages of 18 and 21 , and that this was precisely the reason for questioning higher education and a career.

As noted earlier, according to Orthodox Jewish religious gender-role ideology, the role of the woman is foremost that of wife, mother and homemaker; whereas the man should be involved in religious study and providing for his family's financial needs. This gender arrangement according to the women I interviewed should not be interpreted hierarchically, but rather that the woman's role as the bearer and educator of children, the guardian and pillar of the home is seen as on a par with or, according to some, as even more spiritually elevated than the more public role of men. However, this private-public dichotomy as a specific product of gendered modernity is to some extent also historically contradicted, due to the fact that Orthodox Jewish women are sometimes the main breadwinners of the family, and often even involved in secular employment, in order to support their non-earning husbands' commitment to full-time Talmud study. This tradition is even continued today in certain Haredi or strictly Orthodox Jewish circles (Blumen, 2002). Furthermore, being primarily bound to the domestic sphere and a caring role does not necessarily imply confinement within the walls of the home. Many strictly Orthodox Jewish women are highly active 'outside' through their involvement in all kinds of activities within the community such as teaching, assistance in family businesses, voluntary and charity work, counselling and various social services.

Nonetheless, Orthodox Jewish girls generally are expected (and legally obligated in Belgium) to enjoy a basic education. Yet higher education, especially outside the community boundaries and its protective framework, is not encouraged, partly because it is seen as incompatible with marrying and having children while 'young' as compared with contemporary secular norms. Chaya told me that among the Haredim especially, due to the system of arranged marriages, university or other state education would not look good on their 'marriage curriculum vitae'. It would make it more difficult to find a potential shidduch (match).

The vast majority of the women interviewed, who had all attended college, university or adult education, had combined this with marriage and motherhood. Others did not come from backgrounds or communities in which secular education was tolerated, yet had rebelled significantly without completely leaving 'the fold'. Sarah, in her late forties, was brought up in a type of environment in which 'a girl didn't go to university. You could be bright; it didn't matter, as long as you married the right man.' Yet as an adolescent, Sarah began to protest against the many rules and regulations at school and her father's traditionalist expectations. 
Sarah left home and spent some time in Israel. Upon returning to Antwerp she enrolled at an art college. Ultimately, she did marry an Orthodox Jewish partner and remains religiously observant, yet according to a more modern Orthodox way of life. In her narrative, Sarah therefore interpreted her rebellion not so much as a questioning of her identity as a religious Jewish woman, but primarily as a youngster's conflict with her very traditionalist and controlling father.

Those from more 'open-minded' backgrounds had often married men who themselves had pursued or at least were not against their wives pursuing secular and/or higher education. Josephine, for example, who studied psychology as a newly-wed and young mother, claimed she 'would not have married someone who would not accept her studies and her right to become a professional in her field'. Although 'the household may have suffered a bit', and 'he couldn't handle it during the exam period', on the whole Josephine said her husband did not mind, 'it was not the end of the world', and in fact he was very encouraging. Interviews with some other women revealed that their husbands may have been much less supportive, but this did not deter their wives from choosing and managing to pursue an education in addition to their significant responsibilities within the home.

Whether permitted or discouraged, for most of my interviewees the choice of secular higher education in order to pursue some kind of career was motivated primarily out of personal interest, ambition and desire, rather than pure financial necessity. Although many Orthodox Jewish girls will finish their education with time spent studying at a religious seminary (for girls) abroad, or at most gain a degree from the teacher training programmes in the community schools, the women I interviewed felt the personal need to further their education in other directions. Whereas some had shown an interest in art, law or philology, most chose courses of perhaps a more 'feminine' altruistic type, geared to the caring professions, such as medicine, nursing, psychology, orthopaedics, pedagogical assistance and midwifery. Furthermore, the majority of the latter group desired to work within their own community services rather than in a secular environment, for which - in the end - they were often highly appreciated.

\section{BALANCING ACTS: RECONCILING WORK AND THE FAMILY}

Although themselves exceptions in their educational and professional pathways, many interviewees narrated how they 'juggled' between their studies and work and their familial and domestic responsibilities, including many preparatory tasks related to the weekly Shabbat and religious holidays, being central to their identity as a female Orthodox Jew. When conflicts arose, I was told that family was always the first priority. 
For example, after her degree, Josephine enjoyed her part-time job as a psychologist in a secular environment, a hospital children's ward. As well as a live-in au pair, her family helped out, and a friend saw to it that her three children did not have to stay at school during the lunch break. However, one day her son rebelled, saying he didn't like it at all that she was not home for lunch:

The minute my son complained, I stopped going to Brussels. You have to realise, for me it was a big sacrifice, but I didn't think twice. The minute he told me, 'Mummy we do not like it that you are not there for us', I decided what are my priorities? I didn't consult my husband, I didn't consult anybody ... I decided immediately that my priority is my family.

Josephine made a necessary compromise in, as she herself said, 'sacrificing her career for her family'. Although she missed her former work, she started a private practice at home, to which she is very dedicated and which fills a gap in the market for psychological help in the religious Jewish Antwerp community.

The predominant narrative of Antwerp-born and raised Dina, in her midthirties and a mother of six, could be taken as another example of not only reconciling, but fully integrating her identity as a female Orthodox Jew with a passion for work and personal ambition. After leaving secondary school as a teenager, Dina began the usual path of three years' teacher training at the Beis Yacoov School, where she subsequently took her internship and taught for 10 years. However, at a certain point she felt that 'she had to move on' and was the only girl of her class to attend evening adult education, in order to start work as a pedagogical advisor at two Orthodox Jewish schools.

Dina combines her part-time work with housework, which includes the care of her six children, the weekly preparation of Shabbat, cooking and entertaining family and guests during the many religious holidays. She does have help at home yet claims that many look at her as a 'superwoman', although for her it is 'normal'. On the one hand, Dina subscribed to a dominant type of discourse in which the private role of the woman is exalted:

The role of the woman is vital. There is a big place for the rise of the woman, she must be emancipated ... I am and feel enormously important in my household. If I have the flu and am in bed one day, you know how many people are needed to replace me? ... The woman is also the one who builds up the husband.

Dina professed that her family would never have to suffer due to her professional life, and that her domestic responsibilities were of paramount religious importance: an example being her special knack for having 'aesthetic taste' when it came to preparing the Shabbat table, which gave her 'spiritual pleasure'. 
On the other hand, Dina spoke in a similar way of her dedication, enthusiasm and pride in her 'outside' work. She spoke of her success in dealing with problems using her secular knowledge while incorporating a religious framework, such as in teaching materials; and furthermore of her role as 'bridge builder' when negotiating with secular governmental educational authorities if conflicts arose over her Orthodox school's curriculum. Dina claimed to be very ambitious and said that her work gave her tremendous intellectual and religious fulfilment. For Dina, then, personal ambition and individual fulfilment in an 'outside context', and her exposure to and knowledge of secular society, did not conflict with her traditionally prescribed role and space. She did not see a conflict between aspects of her identity as a religious traditionalist working mother.

\section{TRANSGRESSING AND SEPARATING RELIGIOUS AND SECULAR GENDERED SPACES}

Rivka, a mother of seven and in her late forties, had experienced profound difficulties and severely transgressed her community's expectations, when as a young mother she decided to go on to higher education. Rivka's life-story was indeed exceptional, coming from what she described as an extremely Orthodox background, the Hassidic Belzer community. Her brother contracted meningitis when he was young and became permanently handicapped. The problem for the family, and consequently for Rivka, was that there were no schooling opportunities for children with learning difficulties within an Orthodox Jewish framework in Antwerp at that time. 'I had to do something, there was no choice', she repeatedly said. Rivka went on to higher education in Brussels, gained another university degree in orthopaedics and then specialized further in psychology in another Flemish town: 'I always wanted more knowledge, the feeling of the more you know, the more you don't know.' Over a period of 20 years she has managed to build up and run a school for Jewish children with learning difficulties, which, after a bureaucratic fight of seven years, has only just received state funding.

Rivka started her higher education after marrying and having her first two children:

Everyone was against it, I got no support, not even from my husband, but I had to do it. ... I was up at five in the morning, to get to class at eight, and left my children at my mother's place. I sometimes had to 'drink my own tears like soup'. It was tough, to put it mildly. . . . Yet I was really determined, and no one could stop me.

As for her husband, Rivka maintained: 'Over the years he came to terms with it, and saw it could be no other way.' Although Rivka autonomously 
and ferociously went against every gender norm in her community, including the wish of her own husband, she never considered quitting, or leaving the family and its obligations behind, but embarked on an unusual mission that would nevertheless benefit both her family and the wider community. Thus, she did not interpret her actions in terms of individual autonomy, claiming rather: 'I had to do it, I had no choice.' As for a sense of achievement and/or personal fulfilment in her studies and later career, Rivka similarly maintained that she had never felt self-satisfaction, except for 'maybe three or four times in 20 years some brief moments of accomplishment'. Altruistic help for her brother and others like him had been her primary motivation; individual gratification or success had never been her goal.

Secularly educated women who went on to professions outside their community are few and far between in the relatively closed Antwerp Orthodox Jewish community. One woman I encountered, Miriam, a successful scholar, was absolutely passionate about her work. She gained her degree when she already had two children and took the time she needed to study for a PhD. She then went on to have another two children while working as a voluntary assistant before gaining tenure in a university post. She claimed she had had the possibility to do so because of what she referred to as 'class'; that is, she was not under the financial pressure of having to take paid employment and was able to afford help in the home. For some of my other interviewees, 'class identity' no doubt made the combination of work and family possible. In contrast to those women working within or for their community, Miriam claimed to keep her religious identity separate from her secular workplace. As opposed to Dina, for example, she did not 'bring religion in' to her work, although abiding to halakhic laws such as Shabbat observance did take some juggling. At the same time, she by no means hid her professional activities at home, not even choosing 'a room of her own' in which to work meant that her desk and books were placed in the midst of the spacious family living room.

Although they may have transgressed community and family expectations, many of the narrative positions adopted by my interviewees suggested that within themselves the interviewees did not see any major ideological conflict between prescribed gender roles and going on to higher education and/or having a career. Taking gender equality in secular education and the workplace for granted, they did not feel that this should conflict with a religious gender ideology that emphasizes the important private role of women, although the majority found that, conversely, by no means could liberal gender ideology be fully imported into the religious sphere. Tamar, for example, thought the rule that exempts and therefore relieves women from requirements such as thrice daily prayer and synagogue attendance was a formidable thing, a real freedom rather than oppressive or exclusionary.

These women were ambitious and determined; they regarded themselves as just as capable of professional or intellectual activities as any man. 
Balancing acts were possible by virtue of financial means or practical support that these women could draw on from within the family and community. Tamar, in her mid-thirties and a working mother of four, gathered up the courage to attend university together with one of her gentile colleagues. Yet she emphasized the fact that her study partner eventually had to give up due to pressure from her husband: 'They have emancipation, while I myself as a Jew continued!' Tamar could also count on moral and practical family support, something typical of the close-knit Jewish community, which, she suggested, many contemporary gentile or secular women might be lacking.

\section{FUTURE PROSPECTS FOR WOMEN'S LIFE PATHS}

Regardless of their personal trajectories and in principle support for higher education and careers for Orthodox women, somewhat paradoxically, many of the mothers interviewed tended to revert to a more conservative position when it came to discussing their daughters' futures. Whether at school or in the workplace, my interviewees had encountered very mixed experiences pertaining to conflicting religious and cultural norms. Whereas for some, participating in a secular environment had been exciting and enriching, others emphasized more feelings of exclusion and misunderstanding. The majority nevertheless perceived Belgium's current secular institutions as wholly unsuitable for their own daughters (and sons) to attend.

Josephine, who in the 1960s had been supported by her parents, was still exceptional as an Orthodox Jewish girl in gaining a psychology degree - after quitting studying medicine because of one exam she flunked due to a notorious professor, who called her 'mademoiselle samedi' because of her request for exemption of exams on Saturdays. Yet when one of her daughters wanted to study law at the University of Antwerp, Josephine was very cautious about sending her for she found the situation at universities had changed dramatically since she attended, the two main reasons being 'AIDS and drugs':

It's not that we didn't trust her, we trusted her one hundred percent that she would not hang around with people that are not her cup of tea, but it was a big responsibility to take and she couldn't find a girl from her class to attend the courses with her.

However, her three children did go on to higher education in Israel eventually, where they are currently also living and working.

Hassidic Rivka also claimed that things had changed nowadays. Although she had found her encounter with the secular world difficult, her fellow students and professors had been very understanding, for example giving her copies of their notes when she missed Friday classes 
or the time she gave birth one week before a final exam. One of her daughters currently attends a college in Antwerp where she studies logopaedics. In recent years, there have been a limited number of courses and degrees available to Orthodox Jewish girls in cooperation with secular institutions (including book-keeping and pharmacy assistant), whereby there is strict control of the secular curriculum and teaching by the Jewish schools. 'You would need an enormously strong character to go to university though and I did it when I was already married.' Rivka thought that when she went to university, as compared to nowadays, people were less critical and there was much less verbal aggression among youngsters, it being 'a different world' than today.

Dina did not see much future in Antwerp at all for her daughters and hoped they would be able to study in Israel where there are more options and a framework that is respectful of and not threatening to the Orthodox Jewish way of life. As a pedagogical advisor in Orthodox Jewish schools, Dina had to deal with government officials who according to her were increasing the pressure to make the schools adapt their curriculum. The primary concerns during these recent 'raids', as she called them, were issues of coeducation and sexuality:

Obsessively all the books were opened and the inspectors asked if children in kindergarten are told about procreation and sexuality! I explain that for us sexuality is something elevated, concerning the beautiful relationship between women and men and our children who do not have TV, internet or magazines are so far removed from that, that it would do them more harm than good but they just do not listen.

Dina, who regarded herself as very Orthodox yet 'integrated' and more open to outside society than most, felt it was becoming more and more difficult for her community in Antwerp and sensed that anti-Semitism however subtle - was increasing.

Like Dina, Tamar only started university once she was married and 'more mature'. She definitely understood the general resistance within the Orthodox community against higher secular education, although she claimed that many girls would certainly be intellectually capable of it. On the one hand, she sees the fear of exposure to secular values as very real, given the extent to which the Orthodox girls (and boys) are brought up in a protected environment. This is especially true in the case of a small community like Antwerp, there being 'no one or nothing to fall back on for support and advice'. On the other hand, Tamar was also critical of the way the community perpetuated its distrust of the outside world, which it nevertheless perceives as necessary to maintain its very existence.

All this results in a rather paradoxical situation where girls are dissuaded by the community from pursuing higher education, yet the very same community often takes pride in those who deviate - especially 
when they later provide much-needed services for them. Besides the dearth of 'Orthodox professionals', for a great part of the community there is very much a de facto need for women to join the workforce due to increasing economic pressures. The necessity for a double income follows a general trend in contemporary western society, but also concerns the specific situation in the Antwerp community where employment prospects have become increasingly limited, especially within the diamond industry. Due to a relatively high birth rate and additional domestic responsibilities related to the religious requirements, many working Orthodox Jewish women - especially the strictly Orthodox - endure a heavy 'double burden', yet there is also a trend towards it becoming more acceptable for men to help at home. However, there are only so many employment possibilities within this community that do not require the diplomas only available at secular institutions; and only so many positions for women as teachers at the local Jewish schools, for example.

It is apparent from these life-stories that higher education within the secular world, and the Belgian context in particular, is generally conceived of as potentially threatening to community boundaries; not only to a young woman's (future) role as wife and mother, but as generally incompatible with Orthodox values and way of life. Given that the majority of my interviewees were mature students, they could often handle dealing with exposure to a world very different from their own. However, many did experience difficulties pertaining to the huge cultural differences and conflicts between school regulations and their own cultural practices - such as courses or exams on Fridays and Saturdays, and the more subtle exclusion of not being able to participate in internships and student life (because of the unavailability of kosher food, for example).

Some of these conflicts were of a gendered nature such as compulsory mixed physical education or non-modest clothing requirements (trousers rather than skirts for nursing uniforms, for example). Furthermore, having been brought up in a comparatively gender-segregated environment, coeducation and the free intermingling of male and female students outside class was definitely seen as dangerous in terms of transgressing gender and sexual norms. What can be seen as a general tendency within the Orthodox world and many other traditionalist communities was reflected in the interviewees' discourse: a perception of decline in values pertaining to gender and family relations and sexual morality in the secular world.

By contrast, higher education abroad either in religious or combined institutions that provide secular programmes (as in Israel or the US), or where there is a sufficiently large Orthodox student body to provide facilities and support, is seen as a viable option for many young Orthodox women and men. In Antwerp, however, partly due to the modest size of the community and the influence of Haredi culture, the community itself is becoming increasingly isolationist rather than developing more openness 
to the outside society. This is also due to the larger impact of a move to the right within transnational Orthodoxy - paralleling the global and crosscultural rise in fundamentalism. This is combined with an increase in gender stringency, such as the growing pressure for girls to adhere to ever stricter modesty norms. At the same time, the Belgian state's so-called multicultural policies and various educational institutions that are attempting to 'diversify' their student body have not yet been directed towards the relatively tiny and hitherto self-sufficient Orthodox Jewish community. Given the current climate in which gender issues are often selectively deployed on the multicultural agenda throughout Western Europe, it is unlikely that cross-cultural understanding will deepen and permit a politics of cultural accommodation and group recognition, given the perspective of secular liberal feminist thought in which the Orthodox community continues to be viewed in gender-oppressive terms.

\section{CONCLUSION}

The narratives of exceptional women from various backgrounds and circles in the Orthodox Jewish community of Antwerp revealed idiosyncratic trajectories and multiple subject positions regarding experiences of combining, crossing and transcending religious and secular worlds. This case study not only illustrates how female agency is possible within a religious-traditionalist context - taking specific factors such as class and locality into account - but also how certain dichotomies that characterize secular liberal feminist thought, such as the public autonomous unified self vs values like relationality, care, home and belonging, spirituality and tradition and community, can be challenged. It can be argued that although the women sometimes perpetuated, reinterpreted or transgressed community gender ideology, some of the difficulties they encountered in practice were often very similar to those of the vast majority of women and mothers in liberal society, regardless of ethnicity and religion, where higher education, the workplace and career prospects continue to be modelled according to the autonomous individual - masculine - ideal.

However, the prospects for a broader transformation of gender relations, with an increase in women following their mother's and/or other exceptional women's footsteps, are more grim. Although the narratives testified to the possibility and potential contribution of religiously committed women developing their intellectual and/or professional selves while venturing into the 'outside world'; contemporary religious-traditionalist communities and movements are generally becoming increasingly isolationist in view of what is perceived as a threat to the survival of the community and its traditions. The specificity of Antwerp Jewry (as a small community) and Belgian society - as a liberal democratic West 
European state - must also be taken into account, for, from its side, the latter likewise would not appear particularly open to accommodating cultural and religious diversity. Any kind of solution would minimally require a mutual attempt at understanding and dialogue regarding what both religious and secular ideals and ways of life consist of and may have to offer. From a gender perspective, further research and debate stimulated by 'the religion question in feminism' can no doubt make an important and necessary contribution to such an endeavour.

\section{NOTES}

The research for this article was partly funded thanks to an award from the Hadassah-Brandeis Institute at Brandeis University. The author also wishes to thank the many interviewees in Antwerp and in London for their valuable feedback on earlier versions of this article as well as that of the two anonymous referees.

1. It can be argued that, until recently, both modern and postmodern feminist theoretical thought produced since the second wave feminist movement can predominantly be characterized as either avoiding or sceptical of religion or even anti-religious (see Fernandes, 2005; Lelwica, 1998). Feminist theology is often considered a separate specialization, and despite a long history of research on women and religion in disciplines such as feminist history and the social sciences, this work has only had a marginal impact or gained recognition only recently in feminist theory or secular 'mainstream' gender and women's studies as purportedly interdisciplinary fields (Longman, 2003).

2. (Widely published) social scientific research that addresses the lives of Orthodox Jewish women has been undertaken among different groups and varies in interpretative emphases. The vast majority of research on Orthodox Jewish women's lives nevertheless applies to the specific geographical, cultural and political contexts of either North America or Israel. For social scientific research on women critical of or concerned with expanding Orthodox Jewish women's position within the religious sphere, see, for example, El-Or (2002), Fishman (1995) and Hartman Halbertal (2002); for secular women 'turning' to Orthodoxy, see Davidman (1991), Kaufman (1993) and Manning (1999); and for studies of Haredi (strictly Orthodox) Jewish women, see, for example, Calpan (2003), El-Or (1994), Longman (2007) and Yuval-Davis (1999).

3. Originally Hassidism was a mystical movement with roots in 18th-century Eastern Europe and can be divided into various Hassidic groups each with their own spiritual leader, the rebbe, such as the Belzer, Satmar, Ger, Bobover, all having their own distinct place of origin (hence their names), customs, way of dress, etc. Mitnagdim were historically Hassidism's opponents but today are also viewed as a specific branch of strictly Orthodox Jewry.

4. Pseudonyms have been used throughout this text in order to protect the identity of the interviewees.

5. The Beis Yacoov movement dates from the beginning of the 20th century, when the first religious schools for Jewish girls were established in Eastern Europe, fearing increased assimilation among girls who only received informal education in Jewish knowledge. Beis Yacoov schools throughout the world today provide a combination of secular and in-depth religious education, but do not teach Talmud (Oral Law). 


\section{REFERENCES}

Bloom, Leslie R. (1998) Under the Sign of Hope: Feminist Methodology and Narrative Interpretation. Albany, NY: State University of New York Press.

Blumen, Orna (2002) 'Criss-Crossing Boundaries: Ultraorthodox Jewish Women Go to Work', Gender, Place, and Culture 9(2): 133-51.

Brink, Judy and Joan Mencher, eds (1997) Mixed Blessings: Gender and Religious Fundamentalism Cross Culturally. New York and London: Routledge.

Buitelaar, Marjo (2006) ' "I Am the Ultimate Challenge": Accounts of Intersectionality in the Life-Story of a Well-Known Daughter of Moroccan Migrant Workers in the Netherlands', European Journal of Women's Studies 13(3): 259-76.

Calpan, Kimmy (2003) 'The Internal Popular Discourse of Israeli Haredi Women', Archives de Sciences Sociales des Religions 46(123): 77-101.

Davidman, Lynn (1991) Tradition in a Rootless World: Women Turn to Orthodox Judaism. Berkeley, Los Angeles and Oxford: University of California Press.

El-Or, Tamar (1994) Educated and Ignorant: Ultraorthodox Jewish Women and Their World. Boulder, CO: Lynne Rienner.

El-Or, Tamar (2002) Next Year I Will Know More: Literacy and Identity among Young Orthodox Women in Israel. Detroit, MI: Wayne State University Press.

Fernandes, Leela (2005) Transforming Feminist Practice: Non-Violence, Social Justice and the Possibilities of a Spiritualised Feminism. San Francisco: Aunt Lute Books.

Fishman, Sylvia Barack (1995) A Breath of Life: Feminism in the American Jewish Community. Hanover and London: Brandeis University Press.

Gluck, Sherna Berger and Daphne Patai (1991) Women's Words: The Feminist Practice of Oral History. London: Routledge.

Hartman Halbertal, Tova (2002) Appropriately Subversive: Modern Mothers in Traditional Religions. Cambridge, MA: Harvard University Press.

Kaufman, Debra R. (1993) Rachel's Daughters: Newly Orthodox Jewish Women. New Brunswick, NJ: Rutgers University Press.

Klatch, Rebecca E. (1994) 'Women of the New Right in the United States: Family, Feminism, and Politics', pp. 367-88 in V.M. Moghadam (ed.) Identity Politics and Women: Cultural Reassertions and Feminisms in International Perspective. Boulder, CO: Westview Press.

Lelwica, Michelle M. (1998) Contribution to Roundtable: Feminists and Religion: 'From Superstition to Enlightenment to the Race for Pure Consciousness: Anti-Religious Currents in Popular and Academic Feminist Discourse', Journal of Feminist Studies in Religion 14(2): 108-23.

Longman, Chia (2003) 'Readers in Gender and Religion: Welcome Introductions to a Marginalised Field', European Journal of Women's Studies 10(2): 240-5.

Longman, Chia (2007) ' "Not Us But You Have Changed": Discourses of Difference and Belonging among Haredi Women', Social Compass. Revue Internationale de Sociologie de la Religion/International Review of Sociology of Religion 54(1): 77-95.

Mack, Phyllis (2003) 'Religion, Feminism and the Problem of Agency: Reflections on Eighteenth-Century Quakerism', Signs: Journal of Women in Culture and Society 29(1): 149-77.

Mackenzie, Catriona and Natalie Stoljar, eds (2000) Relational Autonomy: Feminist Perspectives on Autonomy, Agency and the Social Self. New York and Oxford: Oxford University Press.

Mahmood, Saba (2005) Politics of Piety: The Islamic Revival and the Feminist Subject. Princeton, NJ: Princeton University Press. 
Manning, Christel (1999) God Gave Us The Right: Conservative Catholic, Evangelical Protestant, and Orthodox Jewish Women Grapple with Feminism. New Brunswick, NJ: Rutgers University Press.

Phillips, Anne (2007) Multiculturalism without Culture. Princeton, NJ: Princeton University Press.

Prins, Baukje (2006) 'Narrative Accounts of Origins: A Blind Spot in the Intersectional Approach?', European Journal of Women's Studies 13(3): 277-90.

Pritchard, Elizabeth (2006) 'Agency without Transcendence', Culture and Religion 7(3): 263-89.

Shachar, Ayelet (2001) Multicultural Jurisdictions: Cultural Differences and Women's Rights. Cambridge: Cambridge University Press.

Yuval-Davis, Nira (1999) 'The Personal is Political: Jewish Fundamentalism and Women's Empowerment', pp. 33-44 in C.W. Howland (ed.) Religious Fundamentalisms and the Human Rights of Women. Basingstoke and London: Macmillan Press.

Chia Longman is postdoctoral fellow of the Research Foundation-Flanders and affiliated with the Centre for Intercultural Communication and Interaction at Ghent University, Belgium, where she also lectures in gender and anthropology. Her research interests include feminism and multiculturalism in Europe and identity politics among women in religious-traditionalist minorities, including Orthodox Jewish and Muslim women. She has co-edited two books, written articles for various Dutch and international books and journals, and is editor of the Dutch Journal for Gender Studies. Address: Centre for Intercultural Communication and Interaction, Ghent University, Rozier 44, B-9000 Ghent, Belgium. [email: chia.longman@UGent.be] 